\title{
SELECTING CONTROL SITES FOR POST-FIRE ECOLOGICAL STUDIES USING BIOLOGICAL CRITERIA AND MODIS TIME SERIES DATA
}

\author{
Marcos A. Landi*1, Carlos Di Bella ${ }^{2,5}$, Silvia Ojeda ${ }^{3}$, Paola Salvatierra ${ }^{4}$, \\ Juan Argañaraz ${ }^{1}$, and Laura M. Bellis ${ }^{1}$
}

${ }^{1}$ Instituto de Diversidad y Ecología Animal, Universidad Nacional de Córdoba Avenida Velez Sarsfield 299, Córdoba, Córdoba, Argentina 5000

${ }^{2}$ Instituto Nacional de Tecnología Agropecuaria, Instituto de Clima y Agua, Nicolas Repetto y de los reseros 1686, Hurlingham, Argentina HB1712WAA

${ }^{3}$ Centro de Investigación y Estudios en Matemática, Universidad Nacional de Córdoba, Medina Allende s/n, Córdoba, Córdoba, Argentina 5000

${ }^{4}$ Universidad Nacional de Villa María, Arturo Jauretche 1555, Villa María, Córdoba, Argentina 5900

${ }^{5}$ Universidad Nacional de Buenos Aires, Departamento de Métodos Cuantitativos y Sistemas de Información, Avenida San Martín 4453, Ciudad autónoma de Buenos Aires, Argentina C1417DSE

${ }^{*}$ Corresponding author: Tel.: 054-351-4332098 ext. 253; e-mail: marcoslandi1980@gmail.com

\section{ABSTRACT}

Wildland fires play a key role in the functioning and structure of vegetation. The availability of sensors aboard satellites, such as Moderate Resolution Imaging Spectroradiometer (MODIS), makes possible the construction of a time series of vegetation indices (VI) and the monitoring of post-fire vegetation recovery. One of the techniques used to monitor post-fire vegetation is the comparison of a burned site with an adjacent unburned control site. However, to date, there is no objective method available for selecting these unburned control sites. We propose three biological criteria that the unburned sites must meet to be considered control sites, as well as statistical methods based on the analysis of the properties of the Quo-

\section{RESUMEN}

Los incendios juegan un rol clave en el funcionamiento y estructura de la vegetación. La disponibilidad de sensores a bordo de satélites tales como el MODIS, hacen posible la construcción de series de tiempo de índices de vegetación (VI) y el monitoreo de la recuperación de la vegetación post fuego. Una de las técnicas usadas para monitorear la vegetación post fuego de un sitio quemado es su comparación con otro adyacente sin quemar. Por supuesto y hasta el presente, no existe un método objetivo disponible para seleccionar lugares sin quemar que sirvan de testigo. Nosotros proponemos tres criterios biológicos que los lugares sin quemar deberían cumplir para ser considerados como sitios testigo, como así también métodos estadísticos basados en el análisis de las propiedades de las series de tiempo del índice de cociente de vege- 
tient Vegetation Indices time series (QVI), to detect unburned sites that meet the proposed criteria. We also test the performance of the proposed method by checking the pre-fire difference between burned and unburned sites, assuming that the higher the number of met criteria, the greater the similarity. Therefore, we compare the differences between VI time series of burned sites and VI time series of unburned sites with the same vegetation cover that meet three, two, one, and none of the proposed criteria. In addition, we compare the quality of QVI time series that meet three, two, one, and none of the proposed criteria. Our results show that, for Normalized Difference Vegetation Index (NDVI) and Enhanced Vegetation Index (EVI) data, the difference between the time series of burned and unburned sites gradually decreases with the increase of met criteria. A gradual increase is also observed in the quality of the QVI time series with the increase of met criteria. Despite the limitations present in the proposed method, our model represents an advance from the conceptual and methodological standpoints, since this is the first proposal of a statistical method for selecting unburned control sites based on biological criteria. tación (QVI), para detectar sitios no quemados que cumplan con los criterios propuestos. También probamos el desempeño del método propuesto mediante la prueba de las diferencias previas al incendio entre lugares quemados y no quemados, suponiendo que cuanto mayor es el número de criterios concordantes, mayor será la similitud entre sitios. En base a eso, comparamos las diferencias entre las series de tiempo (VI) de los sitios quemados con aquellos (VI) de los no quemados con el mismo tipo de cobertura de vegetación que cumplirían con tres, dos, uno, o ninguno de los criterios propuestos. Adicionalmente comparamos la calidad de las series de tiempo (QV) que cumplían con tres, dos, uno, o ninguno de los criterios propuestos. Nuestros resultados muestran que para datos del índice normalizado de vegetación (NDVI) y del índice de vegetación extendido (EVI), la diferencia entre las series de tiempo de sitios quemados y no quemados disminuye gradualmente con el incremento de los criterios concordantes. Un incremento gradual se observa también en la calidad de las series de tiempo (QVI) con el incremento de los criterios concordantes. A pesar de las limitaciones del método propuesto, nuestro modelo representa un avance tanto desde el punto de vista conceptual como metodológico, dado que es la primera propuesta de un método estadístico para seleccionar sitios testigo no quemados, basados en criterios biológicos.

Keywords: control site selection, ecological experimental design, EVI time series analysis, fire ecology, MODIS, NDVI time series analysis

Citation: Landi, M.A., C. Di Bella, S. Ojeda, P. Salvatierra, J.P. Argañaraz, and L.M. Bellis. 2017. Selecting control sites for post-fire ecological studies using biological criteria and MODIS time series. Fire Ecology 13(2): 1-17. doi: 10.4996/fireecology.130274623

\section{INTRODUCTION}

Wildland fire is a widespread disturbance in terrestrial ecosystems (Flannigan et al. 2013) and plays a key role in the structure and function of vegetation (Bond and Keeley
2005). In the last century, ecological equilibrium has been threatened in many ecosystems, since changes that occurred in climatic and anthropogenic factors have triggered an increase in fire frequency and intensity (Mckenzie et al. 2011). Therefore, robust post-fire monitoring 
tools are needed to understand the post-fire recovery process (Van Leeuwen et al. 2010), which is necessary to design forest management strategies (Casady et al. 2010, Di Mauro et al. 2014).

Wildland fires generally occur as unplanned trials because the time and place of occurrence can seldom be accurately predicted (Ayanz et al. 2003). In this context, satellites are useful tools to monitor fire events because the spectral information captured by on-board sensors makes it possible to obtain information about the fire including the date, location, extent of intensity and severity, and post-fire ecosystem functioning of a fire (Perez-Cabello et al. 2009, Di Bella et al. 2011). The availability of satellites with high temporal resolution and low spatial resolution, such as Moderate Resolution Imaging Spectroradiometer (MODIS), allows daily data collection (Huete et al. 2002). This temporal resolution allows us to build time series datasets (Gitas et al. 2012) and obtain metrics to characterize the post-fire vegetation functioning (Hicke et al. 2003, Goetz et al. 2006, Van Leeuwen 2008, Casady et al. 2010, Di Mauro et al. 2014). Consequently, information generated by this satellite is essential to understanding post-fire vegetation recovery processes and the effect of fires on ecosystem functioning. Despite the significant vegetation variability within each MODIS pixel due to its low spatial resolution, current evidence suggests that Normalized Difference Vegetation Index (NDVI) calculated with MODIS data has a good correlation with NDVI field data (Kovalskyy et al. 2012).

The use of vegetation index (hereafter VI) images obtained from satellite data is one of the most widely used methods to study postfire vegetation recovery (Gitas et al. 2012). These indices have a strong relationship with the amount of biomass (Gasparri et al. 2010), leaf area index (Baret et al. 1989, Baret and Guyot 1991), and the above-ground net primary production (Paruelo and Lauenroth 1998, Paruelo et al. 2001). Therefore, VIs have high correlation with ecosystem functions, (i.e., ecosystem processes that determine the flow rates of energy and matter; Cabello et al. 2012). By far, the most widely used remote sensing VI to assess post-fire recovery is the NDVI (Normalized Difference Vegetation Index; Gitas et al. 2012). Empirical evidence shows that, despite the well-known problems associated with saturation and background signal, NDVI is the VI with the greatest correlation between field measurements taken in different studies of post-fire vegetation recovery (Gitas et al. 2012, Veraverbeke et al. 2012). Another useful VI to characterize vegetation functioning is the Enhanced Vegetation Index (EVI). This index was developed to optimize the vegetation signal since it has improved sensitivity in regions with high biomass and is less affected by both the atmospheric conditions and the canopy background signal (Huete et al. 2002).

One technique used to monitor the time that vegetation needs to return to a similar functional pre-fire state is the comparison of a burned site with an adjacent unburned control site (Gitas et al. 2012, Di Mauro et al. 2014). This method assumes that, without fire, a burned site should exhibit the same vegetation structure and functional behavior as the control site (Lhermitte et al. 2010). Therefore, it is necessary to detect control sites not only with the same vegetation structure before the fire event, but also with a VI time series of similar functional behavior (e.g., Di Mauro et al. 2014). Several field approaches to detect control sites were reported in literature. These studies were based on data about vegetation structure, biodiversity, environmental conditions, plant phenology, and the distance between burned and control sites (Diaz Delgado and Pons 1999, Riaño et al. 2002, Wittenberg et al. 2007, Di Mauro et al. 2014). However, the inaccessibility to some remote and wild study sites complicates the direct field measurements of structural and phenological similarities in ecosystem-scale studies. In addi- 
tion, ecosystem functions have a shorter response time than vegetation structure; so, variations in ecosystem functioning are seldom reflected in vegetation maps because they are oriented to detect structural attributes of vegetation (Paruelo et al. 2001). Therefore, some studies used vegetation maps with a good spatial resolution as complementary information to MODIS time series imagery to ensure structural similarity between burned and control sites (Van Leeuwen 2008, Casady et al. 2010, Di Mauro et al. 2014). In these studies, the authors dealt with the problem of functional similarity by comparing the value of the arithmetic mean of all VI time series of burned sites with the arithmetic mean of all VI time series of unburned control sites. However, the main limitation of this approach is that, by averaging values of the burned area, the intrinsic spatial variability is lost (Gitas et al. 2012). In other studies, such as Lhermitte et al. (2010), authors proposed selecting control sites based on the pre-fire Euclidian distance between the VI time series of burned and unburned sites. However, statistical distance between different time series does not provide information about the nature of the difference or similarity between series (Cuadras 1989, Lhermitte et al. 2011). Hence, in sites with high spatial heterogeneity, selecting the most similar sets of unburned sites does not guarantee a similar vegetation behavior between control and burned sites.

Overall, there are several techniques to compare or measure differences between time series. However, there are no objective criteria for selecting unburned control sites based on the vegetation functional behavior that minimizes the differences between the VI time series of burned and unburned control sites (Gitas et al. 2012). Accordingly, the specific aims of this study were to: 1) propose criteria for selecting control sites that have VI time series of the same functional behavior, 2) propose a statistical method for detecting control sites that meet the set criteria, and 3) test the perfor- mance of the proposed method using data obtained from burned and unburned sites.

\section{METHODS}

\section{Study Area}

We performed the study in the Dry Chaco region, in Santiago del Estero province, Argentina (Figure 1), between $22^{\circ} \mathrm{S}$ and $31^{\circ} \mathrm{S}$, and between $59^{\circ} \mathrm{W}$ and $66^{\circ} \mathrm{W}$ (Kunst et al.

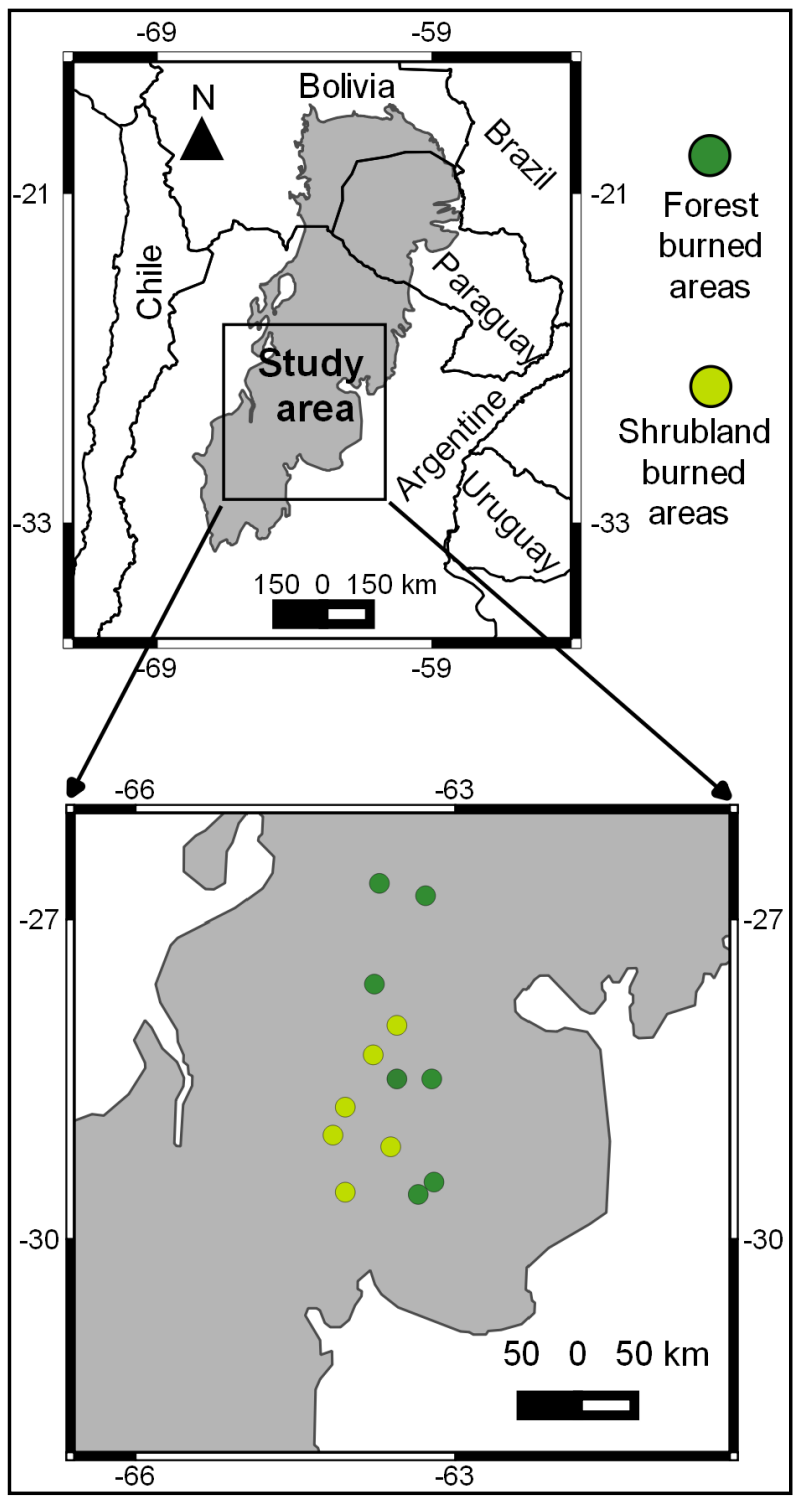

Figure 1. Location of study area. Dark green circles: forest burned areas, light green circles: shrubland burned areas. Grey area: Dry Chaco region. 
2003). The annual rainfall ranges from 400 $\mathrm{mm}$ to $800 \mathrm{~mm}$ (Arambarri et al. 2011). The vegetation is composed of forest, shrubland, and grassland (Kunst et al. 2003, Atala et al. 2008, Bravo et al. 2014). The forest canopy is $6 \mathrm{~m}$ to $9 \mathrm{~m}$ in height and the cover ranges from $15 \%$ to $80 \%$; it is mainly composed of the evergreen species Aspidosperma quebracho-blanco Schltdl. and the deciduous trees Prosopis spp. L. (Kunst et al. 2003). The shrubland consists of short woody vegetation and an herbaceous layer resulting from excessive logging and grazing; it is mainly composed by Acacia praecox Griseb., Celtis chichape (Wedd.) Miq., and Schinus fasciculatus (Griseb) I.M. Johnst. (Kunst et al. 2003). Nomenclature follows Zuloaga and Morrone (1999). The woody species are $3 \mathrm{~m}$ to $5 \mathrm{~m}$ in height and the cover ranges from $35 \%$ to $80 \%$ (Atala et al. 2008).

\section{Satellite Data}

Time series construction. We used data from MODIS Terra imagery (MOD13Q1) to construct NDVI and EVI time series. We downloaded images from the Oak Ridge National Laboratory Distributed Active Archive Center's MODIS Land Product Subsets (https://daac.ornl.gov/MODIS/). This product is atmospherically corrected to surface reflectance and has a spatial resolution of $250 \mathrm{~m} \times$ $250 \mathrm{~m}$, with a temporal resolution of 16 days, resulting in 23 images per year. Since NDVI MODIS Terra dataset has been available from 18 February 2000, we decided to use VI time series that spanned three years before fire events, from 18 February 2000 to the date corresponding to an image prior to each fire event, from August to December 2003.

Fire detection. To detect burned areas, we used the Normalized Burn Ratio (NBR) index (Key and Benson 1999), calculated from Landsat 5 TM images (scenes 229-79 and 22980 from 12 December 2003, resolution $30 \mathrm{~m} \times$ $30 \mathrm{~m})$. We downloaded georeferenced and or- thorectified images from the US Geological Survey (EarthExplorer; http://earthexplorer. usgs.gov/). In order to validate detected burned areas, we overlapped the MODIS (MCD14L) vector Thermal Anomalies Fire product shapefile (Giglio 2010) with NBR images (Figure 2). This product has a spatial resolution of $1 \mathrm{~km} \times 1 \mathrm{~km}$ and a temporal resolution of $6 \mathrm{hr}$, and was downloaded from NASA FIRMS (National Aeronautics and Space Administration Fire Information for Resource Management System; https://earthdata.nasa. gov/earth-observation-data/near-real-time/ firms).

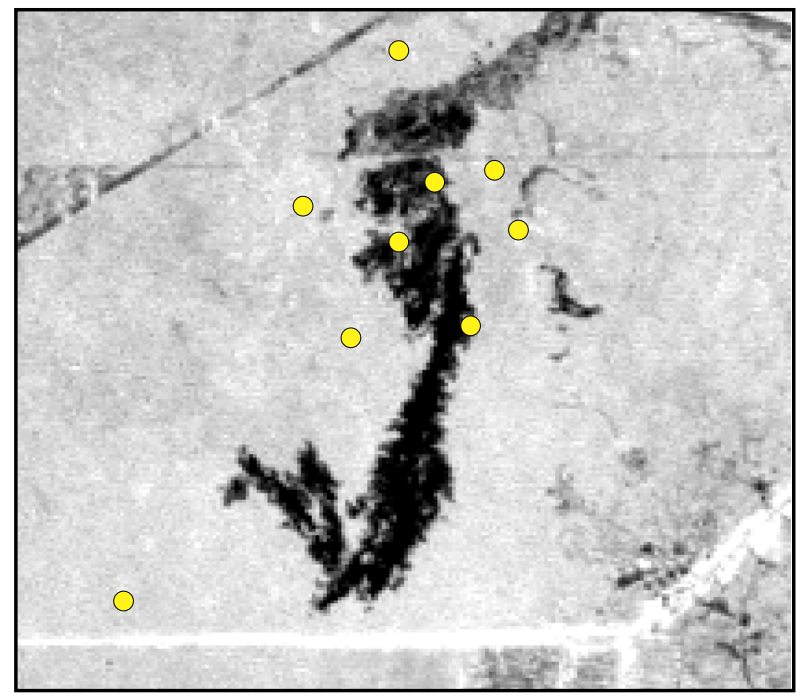

Figure 2. NBR Landsat $5 \mathrm{TM}$ image of a burned area. Yellow circles: MODIS (MCD14L) vector Thermal Anomalies Fire product.

Vegetation map. We used Globcover 2000 vegetation map (Joint Research Centre) to assign vegetation cover to unburned and burned sites. This map is a global vegetation product, has a spatial resolution of $1 \mathrm{~km} \times 1 \mathrm{~km}$ (Eva et al. 2002), and incorporates vegetation field data, NDVI data from SPOT VEGETATION (Saint 1994). This NDVI product has a spatial resolution of $1 \mathrm{~km} \times 1 \mathrm{~km}$, with a temporal resolution of 10 days. Besides, Globcover 2000 incorporates ATSR2 (Závody et al. 1994) satellite data to characterize seasonal behavior of forests, JERS-1 (Rosenqvist 1996) radar 
data to characterize the hydrodynamics of forests, and GTOPO30 topographic data (USGS 2005).

\section{Proposed Criteria and Statistical Methods}

As a first step, we proposed to calculate the point-by-point ratio between the VI time series of one pixel of the burned area of interest $\left(T S_{\mathrm{b}}\right)$, and the VI time series of one pixel of the unburned area $\left(T S_{\mathrm{ub}}\right)$. This unburned area was randomly selected in a buffer area around each burned site (Equation 1; Figure 3, step 1):

$$
Q V I_{\mathrm{TS}_{\mathrm{b}} / \mathrm{TS}_{\mathrm{ub}}}=\frac{T S_{\mathrm{b}}}{T S_{\mathrm{ub}}}
$$

where $T S_{\mathrm{b}}$ is the VI time series of the burned site, and $T S_{\mathrm{ub}}$ is the VI time series of the unburned site

Then, we represented the new time series $\mathrm{QVI}_{\mathrm{TS}_{\mathrm{b}} / \mathrm{TS}_{\mathrm{pb}}}$ according to a classical additive statistical model for time series (Morettin and Castro Toloi 1987, Brockwell and Davis 2002), which is presented in Equation 2:

$$
Q V I_{\mathrm{TS}_{\mathrm{b}} / \mathrm{TS}_{\mathrm{ub}}}=M e_{\mathrm{QVI}}+T_{\mathrm{QVI}}+S_{\mathrm{QVI}}+a_{\mathrm{QVI}}
$$

where $M e_{\mathrm{QVI}}$ is the arithmetic mean; $T_{\mathrm{QVI}}$ is the tendency component, the function that expresses the rate of change of $\mathrm{QVI}_{\mathrm{TS}_{\mathrm{b}} / \mathrm{TS}_{\mathrm{ub}}}$ over time; $S_{\mathrm{QVI}}$ is the seasonality component, the function that expresses the seasonal component of $\mathrm{QVI}_{\mathrm{TS}_{\mathrm{b}} / \mathrm{TS}_{\mathrm{ub}}}$; and $a_{\mathrm{QVI}}$ is the random effect component.

Next, we analyzed the properties of the $\mathrm{QVI}_{\mathrm{TS}_{\mathrm{b}} / \mathrm{TS}_{\mathrm{ub}}}$ time series to test if they met the following proposed criteria. As the first criterion, we proposed that, before the fire, the mean level of photosynthetic activity of the unburned site should not have statistically significant differences from the mean level of photosynthetic activity of the burned site. To detect these unburned sites, we proposed that pre-fire $\mathrm{QVI}_{\mathrm{TS}_{\mathrm{b}} / \mathrm{TS}_{\mathrm{ub}}}$ time series had $M e_{\mathrm{QVI}}=1$ (Figure 3, step 2), because if Me was 1, then
$T S_{\mathrm{b}}$ and $T S_{\mathrm{ub}}$ had the same mean. To test that $M e_{\mathrm{QVI}}=1$, we proposed using $\mu$ as an estimator (Efron 1979, Efron and Tibshirani 1986) with a $95 \%$ confidence interval. To break the temporal autocorrelation of the data, the lower and upper limits of $M e_{\mathrm{QVI}}$ were estimated by bootstrapping with replacement (Efron 1979, Efron and Tibshirani 1986), using 1000 iterations and extracting $50 \%$ of the data from each iteration.

As a second criterion, we proposed that the slope of the VI time series of burned and unburned sites should not have statistically significant differences (Figure 3, step 3), because differences in this parameter indicate that the photosynthetic activity of both sites evolved differently in magnitude or direction over time. To test this criterion, we proposed that $\mathrm{QVI}_{\mathrm{TS}_{\mathrm{b}} / \mathrm{TS}_{\mathrm{ub}}}$ should exhibit a null $T_{\mathrm{QVI}}$. To test if $T_{\mathrm{QVI}}$ was null, we proposed using the nonparametric Spearman Rank Correlation Test (Morettin and Castro Toloi 1987, McLeod et al. 1991, Yue et al. 2002).

As a third criterion, we proposed that, in each season of the year, burned and unburned sites should have a mean level of photosynthetic activity without statistically significant differences (Figure 3, step 4), since these differences indicate that burned and unburned sites have a different functional behavior for at least one season of the year. To test this criterion, we proposed that $\mathrm{QVI}_{\mathrm{TS}_{\mathrm{b}} / \mathrm{TS}_{\mathrm{ub}}}$ should have a null $S_{\mathrm{QVI}}$, because the existence of differences between burned and unburned sites in the mean of VI for at least one season of the year would generate a seasonal pattern in the $\mathrm{QVI}_{\mathrm{TS}_{\mathrm{b}} / \mathrm{TS}_{\mathrm{ub}}}$ time series. To test if $S_{\mathrm{QVI}}$ was null, we proposed testing that each season of the

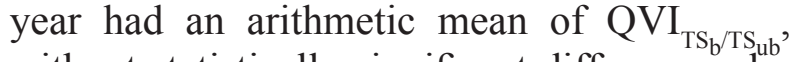
without statistically significant differences, by applying the nonparametric Friedman test (Morettin and Castro Toloi 1987, Sutradhar et al. 1995). To implement the test, we used each season as a treatment (four treatments) and the year as a block (three blocks); thus, the Friedman test was implemented using 12 data 


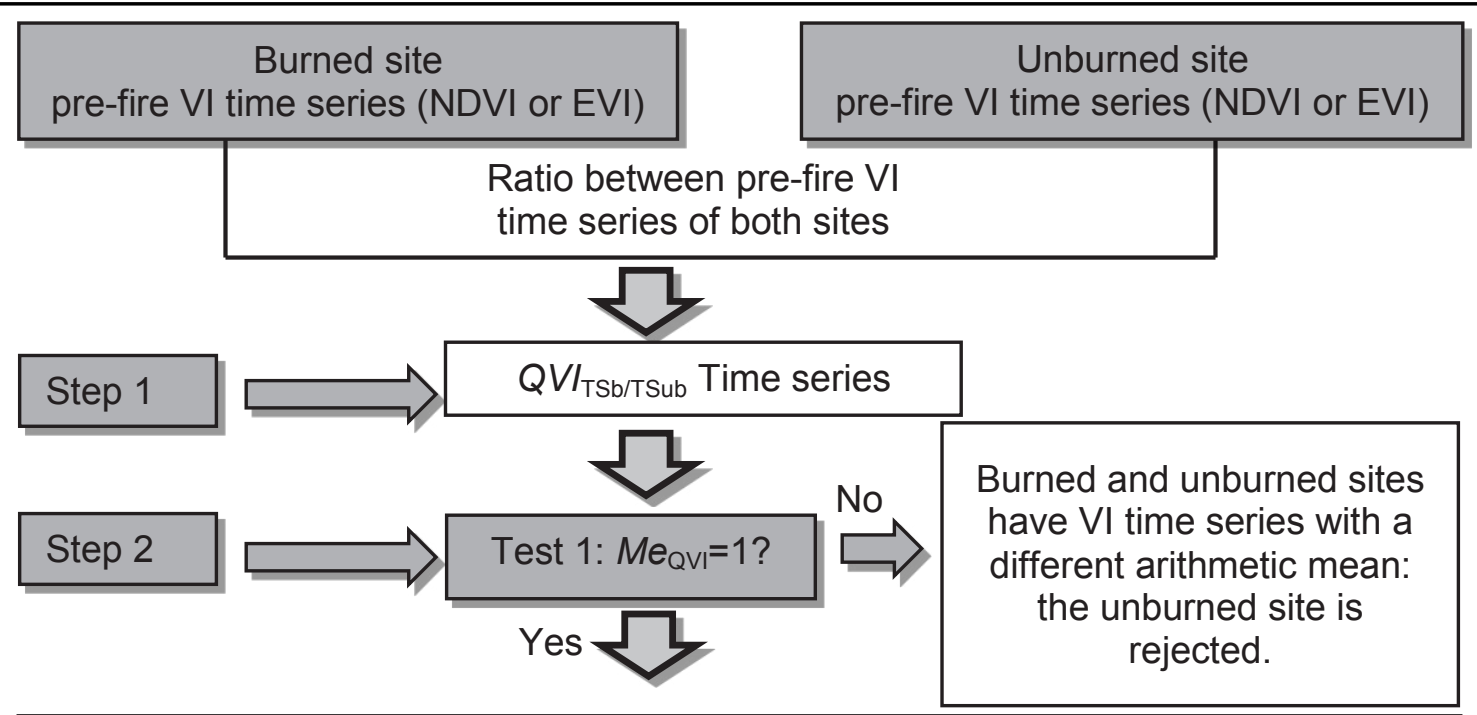

VI time series of both sites have the same arithmetic mean.

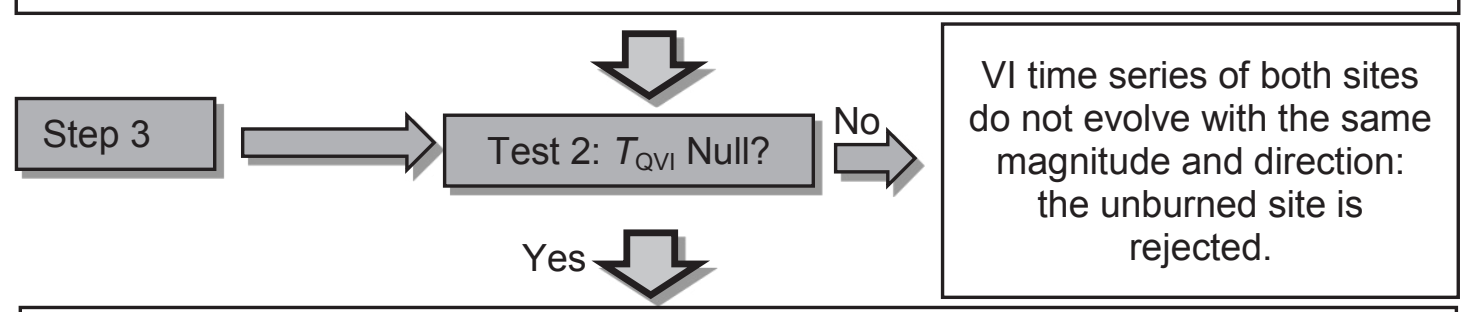

The time series of both sites evolve with the same magnitude and direction.

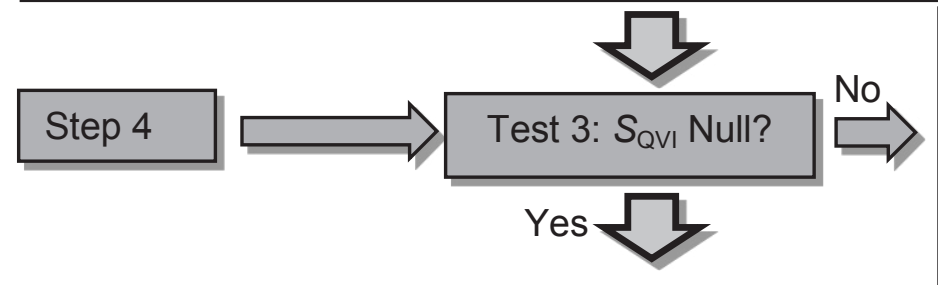

Burned and unburned sites have a different arithmetic mean of VI time series for at least one season of the year: the unburned site is rejected.

In every season of the year burned and unburned sites have an arithmetic mean of VI without statistically significant differences.

The unburned site that passes the three tests is a control site.
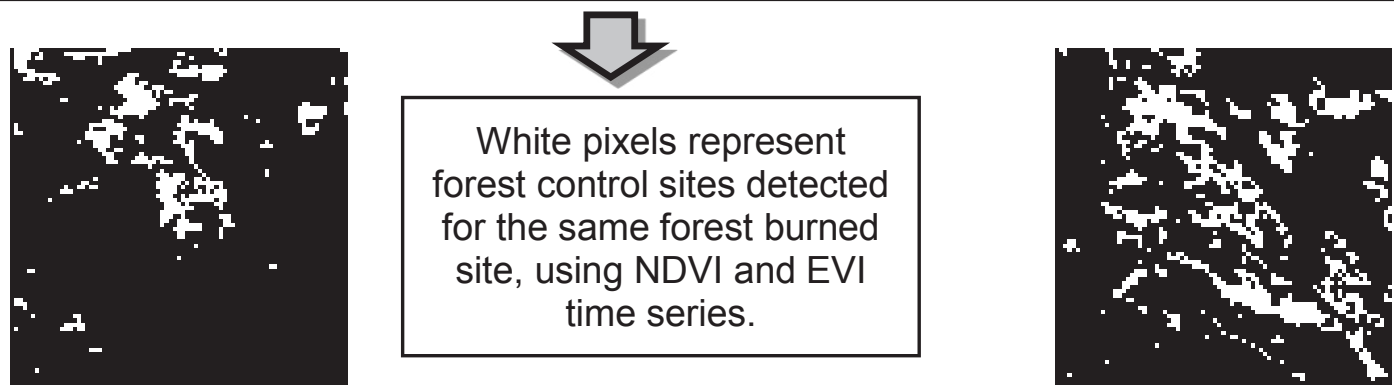

Control sites detected with NDVI data

Control sites detected with EVI data

Figure 3. Flowchart of the proposed method. 
points. To obtain each data point, we averaged the $\mathrm{QVI}_{\mathrm{TS}_{\mathrm{b}} / \mathrm{TS}_{\mathrm{ub}}}$ data corresponding to each season. We used this nonparametric test to avoid the correlation between repetitions, because, in this way, we increased the time lag between replicates of each treatment to one year instead of one data point every 16 days (Franzini and Harvey 1983, Morettin and Castro Toloi 1987, Sutradhar et al. 1995). The $\mathrm{QVI}_{\mathrm{TS}_{\mathrm{b}} / \mathrm{TS}_{\mathrm{ub}}}$ time series that met the three proposed criteria could be considered as a random noise with $\mu$ $=1$, since the classical additive statistical model assumes that a time series without tendency and seasonality is a random noise (Morettin and Castro Toloi 1987, Brockwell and Davis 2002).

The unburned sites generating $\mathrm{QVI}_{\mathrm{TS}_{\mathrm{b}} / \mathrm{TS}_{\mathrm{ub}}}$ that met the three proposed criteria could be considered control sites because they not only had the same vegetation cover as the burned sites, but also the same functional behavior. Figure 4 shows the vegetation structure of actual burned and unburned sites that met the three proposed criteria. Figure 5A shows that the NDVI time series of a burned site and of an unburned site that met the three proposed criteria had the same behavior with occasional differences. And figure 5B shows that the $\mathrm{QVI}_{\mathrm{TS}_{\mathrm{b}} / \mathrm{TS}_{\mathrm{ub}}}$ that met the three proposed criteria was centered around 1 and only a few data points were as high as $10 \%$.

\section{Testing the Performance of the Proposed Method}

To test the performance of the method, we assumed that, if it is correct, the pre-fire functional similarity between burned and unburned sites would increase with the increase of met criteria of unburned sites. Therefore, we compared the differences between VI time series of burned sites and VI time series of unburned sites with the same vegetation cover that met three, two, one, and none of the proposed criteria. In addition, we expected that the quality of $\mathrm{QVI}_{\mathrm{TS}_{\mathrm{b}} / \mathrm{TS}_{\mathrm{ub}}}$ time series would increase with

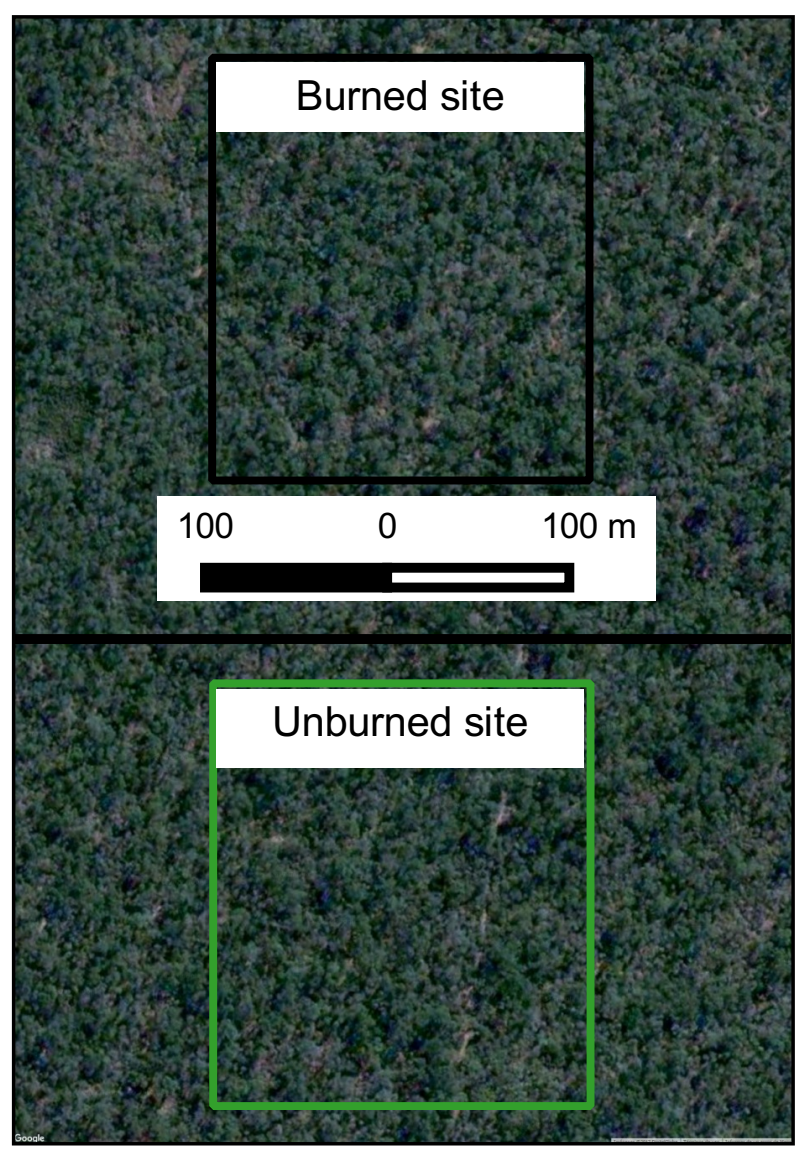

Figure 4. Structure of actual burned and unburned sites that met the three proposed criteria.

the increase of met criteria of unburned sites. Therefore, we compared the width of the confidence interval for $\mathrm{QVI}_{\mathrm{TS}_{\mathrm{b}} / \mathrm{TS}_{\mathrm{ub}}}$ time series that met three, two, one, and none of the proposed criteria. Finally, we expected a decrease in the variability of VI time series of unburned sites with the increase of met criteria, because the VI time series of unburned sites that met the three proposed criteria should be very similar to the VI time series of the burned sites. In turn, VI time series of unburned sites that did not meet the three proposed criteria could be similar or dissimilar to the VI time series of the burned sites.

For this study, we constructed VI time series from forest and shrubland covers using NDVI and EVI data sets (Huete et al. 2002). We used forest and shrubland areas because 


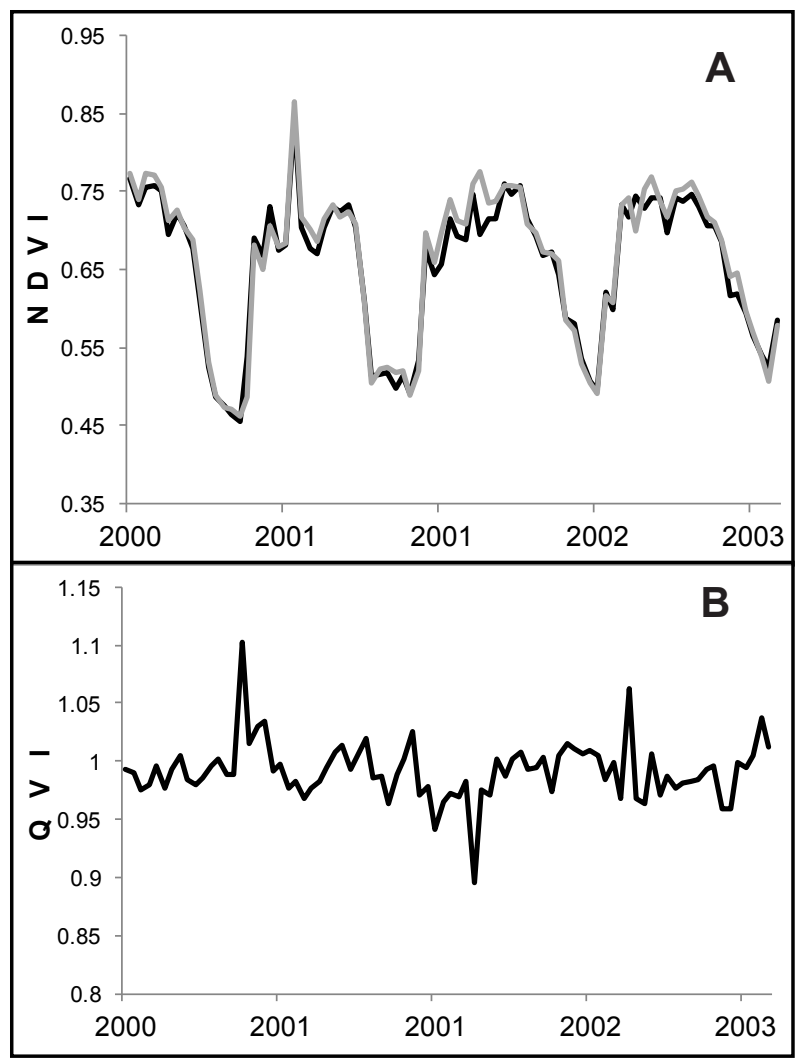

Figure 5. A) NDVI time series of a burned site (black) and an unburned site (gray) that met the three proposed criteria. B) QVI time series that met the three proposed criteria.

they are the largest land covers in the region and exhibit VI time series with different interand intra-annual behaviors (Clark et al. 2010). We also used NDVI and EVI datasets because they exhibit differences in the range of variation and in the sensitivity to vegetation structure, chlorophyll activity, and soil water status (Huete et al. 2002, Clark et al. 2010, Paruelo et al. 2014), thus providing different types of biological information to select the control sites. We manually selected 20 burned forest sites distributed across seven burned areas, and 20 burned shrubland sites distributed across six burned areas (Figure 1). Each burned site had an area of $250 \mathrm{~m} \times 250 \mathrm{~m}$ (1 MODIS pixel). We detected each burned area by visually analyzing the NBR images and the vector Thermal Anomalies Fire product shapefile (Figure 2). All areas were burned in 2003 at different points across an area of $50000 \mathrm{~km}^{2}$ of the Chaco region. For each burned site, we randomly selected 40 unburned sites with VI time series that met the three proposed criteria and had the same vegetation cover before the fire, 40 that met two criteria, 40 that met one criterion, and 40 that did not meet any criteria. We used a total of $12840 \mathrm{VI}$ time series for this work: 40 time series of burned sites plus 12800 VI time series of unburned sites ( 2 plant cover $\times 20$ burned plots $\times 40$ unburned sites per number of met criteria $\times 4$ number of met criteria $\times 2$ vegetation indices $=12800$ ). Unburned sites were selected from a buffer area of $10 \mathrm{~km}$ around each burned site. Unburned site selection and statistical tests were performed automatically using IDL 71 (ITT Visual Information Solutions 2009).

\section{Comparison of Time Series}

We measured the pre-fire differences between VI time series of each burned site and unburned sites that met three, two, one, and none of the proposed criteria using two measures: 1) Mean Proportional Difference (MPD; Equation 3), and 2) Mean Square Error (MSE; Equation 4) - the latter being more sensitive to outliers than the former (Lhermitte et al. 2010, Lhermitte et al. 2011). The quality of the $\mathrm{QVI}_{\mathrm{TS}_{\mathrm{b}} / \mathrm{TS}_{\mathrm{ub}}}$ time series generated from the possible control sites was measured using the Width of the Confidence Interval (WCI) of $M e_{\mathrm{QVI}}$.

$$
\begin{aligned}
& M P D=\frac{\sum_{i=0}^{n=1} \frac{\operatorname{Abs}\left(S b_{i}-S u b_{i}\right)}{S b_{i}}}{N}, \\
& \text { and } \\
& M S E=\sqrt{\frac{\sum_{i=0}^{n=1}\left(T S b_{\mathrm{i}}-T S u b_{\mathrm{i}}\right)^{2}}{N}},
\end{aligned}
$$

where $T S b_{\mathrm{i}}$ is the VI value at time $i$ of the burned site time series, $T S u b_{\mathrm{i}}$ is the VI value at the $i$ of the unburned site time series, $N$ is the 
number of observations in the time series, and Abs is the absolute value function.

\section{Data Analysis}

We used the nonparametric Kruskal-Wallis test (Sheskin 2004) to compare MPD and MSE differences and WCI of QVI $\mathrm{TS}_{\mathrm{b}} / \mathrm{TS}_{\mathrm{ub}}$ time series, using the number of met criteria as treatment. We verified that VI time series variability of unburned sites decreased with the increase of met criteria by unburned sites. For this, we performed an $F$ test for homogeneity of variances to compare the variability of MPD and MSE differences and WCI values obtained for each set of time series (Sheskin 2004), using the number of met criteria as treatment.

\section{RESULTS}

In forests, average differences between VI time series of burned and unburned sites gradually decreased with the increase of met criteria (Figure 6; $\mathrm{MPD}_{\mathrm{NDVI}} P<0.0001, \chi^{2}=$ 1025.4; $\mathrm{MPD}_{\mathrm{EVI}} P<0.0001, \chi^{2}=383.4$; $\mathrm{MSE}_{\mathrm{NDVI}} P<0.0001, \chi^{2}=273.4 ; \mathrm{MSE}_{\mathrm{EVI}} P<$ $\left.0.0001, \chi^{2}=234.6\right)$. In the NDVI data set, VI time series that met the three criteria had a MPD and a MSE nearly $50 \%$ smaller than the series that did not meet any criteria. For the EVI data set, we observed that these reductions were close to $30 \%$ for MPD and MSE. The WCI values measured for the $\mathrm{QVI}_{\mathrm{TSb} / \mathrm{TSub}}$ series followed a similar reduction pattern (WCI $_{\mathrm{NDVI}} P<0.0001, \chi^{2}=357.4$ WCI $_{\mathrm{EVI}} P<$ $\left.0.0001, \chi^{2}=217.1\right)$. In the NDVI data set, the WCI values of the time series that met the three criteria were about $29 \%$ smaller than series that did not meet any criteria; whereas for the EVI data set, this reduction was close to $17 \%$. Unburned sites showed a gradual decrease in the variability of the time series with the increase of met criteria (Table 1). The variability measured for unburned sites that met the three criteria were five to ten times smaller than the measured variability of the

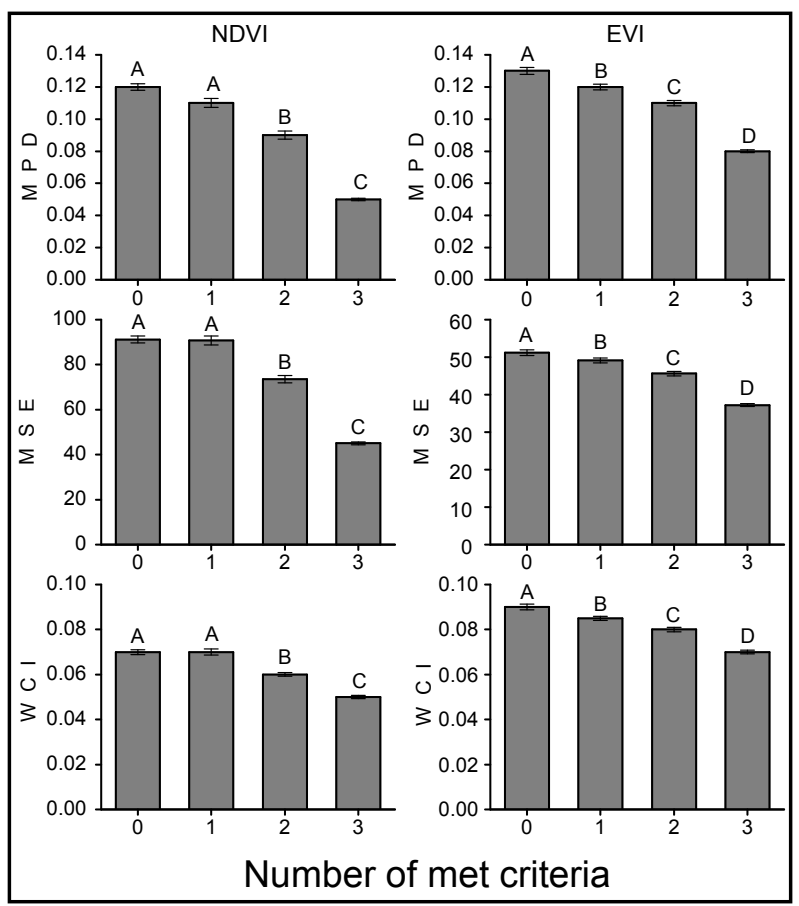

Figure 6. Mean value and standard deviation of MPD (Mean Proportional Difference) and MSE (Mean Square Error) differences, and WCI (Width of the Confidence Interval) obtained for forest VI time series that met three, two, one, and none of the proposed criteria. Different letters indicate significant differences (Kruskal-Wallis test, $P<0.05$ ).

unburned sites that did not meet any criteria (Table 1).

Results obtained for shrubland VI time series were similar to those of the forest VI time series. The differences between the VI time series of burned and unburned sites gradually decreased with the increase of the met criteria (Figure 7; $\mathrm{MPD}_{\mathrm{NDVI}} P<0.0001, \chi^{2}=495$; $\mathrm{MPD}_{\mathrm{EVI}} P<0.0001, \chi^{2}=270.6 ; \mathrm{MSE}_{\mathrm{NDVI}} P<$ $0.0001, \chi^{2}=452.3 ; \mathrm{MSE}_{\mathrm{EVI}} P<0.0001, \chi^{2}=$ 273.4). For the NDVI data set, VI time series that met the three criteria had a MPD $45 \%$ smaller and a MSE 36\% smaller than series that did not meet any criteria. For the EVI data set, these reductions were about $30 \%$ for MPD and 36\% for MSE. The WCI values measured for $\mathrm{QVI}_{\mathrm{TS}_{\mathrm{b}} / \mathrm{TS}_{\mathrm{Hb}}}$ series followed a similar reduction pattern $\left(\mathrm{WCI}_{\mathrm{NDVI}} P<0.0001, \chi^{2}\right.$ 
Table 1. Variance measured for MPD (Mean Proportional Differences) and MSE (Mean Square Error) differences, and WCI (Width of the Confidence Interval) obtained for forest time series that met three, two, one, and none of the proposed criteria. Different letters indicate significant differences $(F$ test, $P<$ $0.05)$.

\begin{tabular}{|c|c|c|c|c|c|c|}
\hline \multirow{2}{*}{$\begin{array}{l}\text { Number of } \\
\text { met criteria }\end{array}$} & \multicolumn{2}{|c|}{ MPD } & \multicolumn{2}{|c|}{ MSE } & \multicolumn{2}{|c|}{ WCI } \\
\hline & NDVI & EVI & NDVI & EVI & NDVI & EVI \\
\hline 0 & $3.5 \times 10^{-3} \mathrm{a}$ & $3.7 \times 10^{-3} \mathrm{a}$ & $1867 \mathrm{a}$ & $536.2 \mathrm{a}$ & $1 \times 10^{-3} \mathrm{a}$ & $13 \times 10^{-3} \mathrm{a}$ \\
\hline 1 & $0.01 \mathrm{~b}$ & $2.6 \times 10^{-3} \mathrm{~b}$ & $3316 b$ & $313.9 \mathrm{~b}$ & $1.5 \times 10^{-3} \mathrm{~b}$ & $7 \times 10^{-4} \mathrm{~b}$ \\
\hline 2 & $4 \times 10^{-3} \mathrm{c}$ & $2.2 \times 10^{-3} \mathrm{c}$ & $2286.4 \mathrm{c}$ & $277.1 \mathrm{c}$ & $5 \times 10^{-4} \mathrm{c}$ & $8 \times 10^{-4} c$ \\
\hline 3 & $4 \times 10^{-4}$ & $8 \times 10^{-3} \mathrm{~d}$ & $340.9 \mathrm{~d}$ & $108.5 \mathrm{~d}$ & $4 \times 10^{-4} \mathrm{~d}$ & $5 \times 10^{-4} \mathrm{~d}$ \\
\hline
\end{tabular}

$\left.=116.88 ; \mathrm{WCI}_{\mathrm{EVI}} P<0.0001, \chi^{2}=109.22\right)$. In the NDVI data set, the WCI values of the time series that met the three criteria were about $25 \%$ smaller than series that did not meet any criteria; whereas, for the EVI data set, this reduction was close to $29 \%$. Unburned sites showed a gradual decrease in the variability of

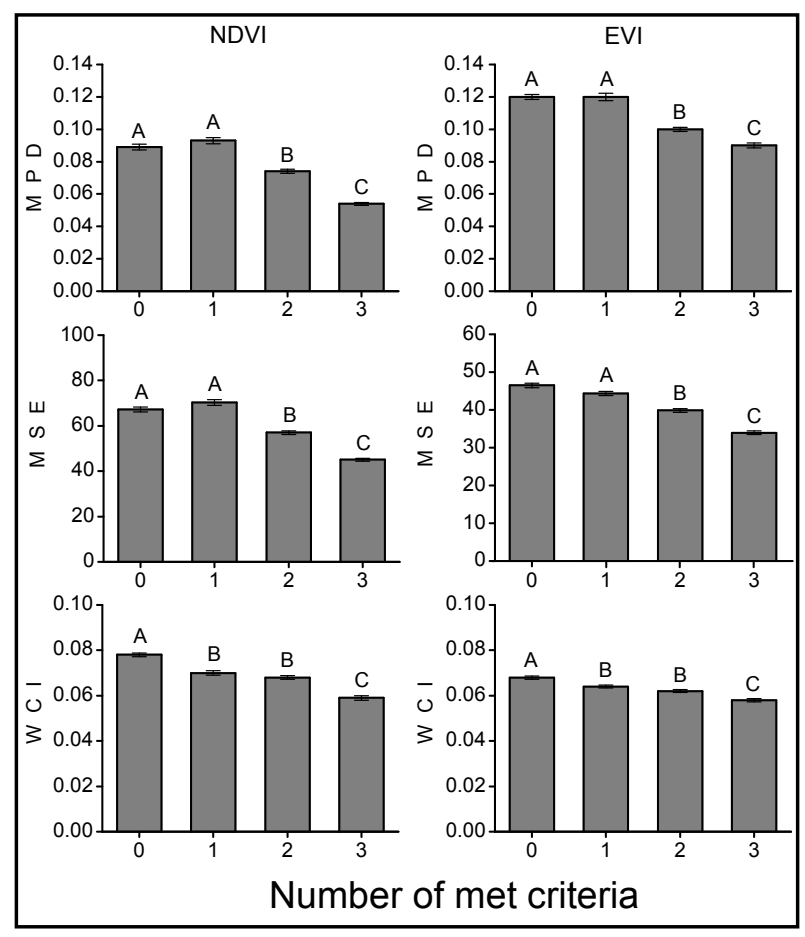

Figure 7. Mean value and standard deviation of MPD (Mean Proportional Difference) and MSE (Mean Square Error) differences, and WCI (Width of the Confidence Interval) obtained for shrubland VI time series that met three, two, one, and none of the proposed criteria. Different letters indicate significant differences (Kruskal-Wallis test, $P<0.05$ ). the time series with the increase of met criteria (Table 2). The variability measured for sites that met the three criteria were two to five times smaller than the variability measured for unburned sites that did not meet any criteria (Table 2). The only exception to this pattern was the WCI of the EVI data set.

\section{DISCUSSION}

The biological criteria and statistical method proposed herein to select control sites yielded satisfactory results. We observed a gradual decrease in MPD, MSE, and WCI values with the increase of met criteria. This pattern indicates that the similarity of VI time series between burned and unburned sites increased with the increase of met criteria. Hence, the functional similarity also increased, because the VI are related to biomass, green cover, leaf area index, and fraction of absorbed photosynthetically active radiation (Huete et al. 2002, Paruelo 2008). We also observed a gradual reduction in the variability of MPD, MSE, and WCI values with the increase of met criteria, which means that VI time series that met the three criteria were very similar to the VI time series of the burned sites; whereas, VI time series of unburned sites that did not meet the three proposed criteria were similar or dissimilar to the VI time series of the burned sites.

The comparison of the average values of MPD, MSE, and WCI values obtained for NDVI and EVI time series showed similar pat- 
Table 2. Variance measured for MPD (Mean Proportional Differences) and MSE (Mean Square Error) differences, and WCI (Width of the Confidence Interval) obtained for the shrubland time series that met three, two, one, and none of the proposed criteria. Different letters indicate significant differences ( $F$ test, $P<0.05)$.

\begin{tabular}{ccccccc}
\hline \multirow{2}{*}{$\begin{array}{c}\text { Number of } \\
\text { met criteria }\end{array}$} & \multicolumn{2}{c}{ MPD } & \multicolumn{2}{c}{ MSE } & \multicolumn{2}{c}{ WCI } \\
\cline { 2 - 7 } NDVI & EVI & NDVI & EVI & NDVI & EVI \\
\hline 0 & $2.2 \times 10^{-3} \mathrm{a}$ & $3.5 \times 10^{-3} \mathrm{a}$ & $959.7 \mathrm{a}$ & $272.7 \mathrm{a}$ & $7 \times 10^{-4} \mathrm{a}$ & $4 \times 10^{-4} \mathrm{a}$ \\
1 & $2.9 \times 10^{-3} \mathrm{a}$ & $2 \times 10^{-3} \mathrm{~b}$ & $1255 \mathrm{~b}$ & $274.8 \mathrm{a}$ & $8 \times 10^{-4} \mathrm{a}$ & $3 \times 10^{-4} \mathrm{a}$ \\
2 & $1.1 \times 10^{-3} \mathrm{a}$ & $1.5 \times 10^{-3} \mathrm{c}$ & $479 \mathrm{c}$ & $166.6 \mathrm{~b}$ & $5 \times 10^{-4} \mathrm{~b}$ & $3 \times 10^{-4} \mathrm{a}$ \\
3 & $4 \times 10^{-4} \mathrm{~b}$ & $1.4 \times 10^{-3} \mathrm{c}$ & $218.9 \mathrm{~d}$ & $163.9 \mathrm{c}$ & $6 \times 10^{-4} \mathrm{~b}$ & $4 \times 10^{-4} \mathrm{a}$ \\
\hline
\end{tabular}

terns of variation (Figures 6 and 7). However, for both forest and shrubland covers, the average MPD and WCI values for the NDVI data were about half of the values for the EVI data. These differences may be attributed to the information contained in each index. The NDVI index provides information not only about plant photosynthetic activity, but also about the characteristics and water status of the substrate (Huete et al. 2002, Paruelo 2008). Therefore, by using the NDVI time series, we can select sites with greater similarity in photosynthetic activity, type of substrate, and soil water dynamics than by using the EVI time series. On the other hand, the EVI index is more sensitive to structural canopy variations, including leaf area index, canopy type, plant physiognomy, and canopy architecture (Gao et al. 2000, Huete et al. 2002), than NDVI. Therefore, for ecological studies, we recommend selecting as control sites those unburned sites that meet the three criteria with both VI time series. As a consequence, the functional similarity between sites will be maximized

Comparing the results obtained between forest and shrubland, we observed that variability was the main difference. The probability to select an unburned site that meets the three proposed criteria and has a great difference from the time series of a burned site was smaller for forests than for shrublands. This is because, in forests, the reduction in the variance was twice higher than in shrublands (Tables 1 and 2). Consequently, the results from the method obtained for shrubland covers need to be examined more carefully. These differences between cover types may be attributed to the different levels of degradation and high spatial heterogeneity typical of shrublands (Atala et al. 2008), which are characterized by a high percentage of a herbaceous plant cover and bare soil (Kunst et al. 2003, Arambarri et al. 2011). Hence, due to the phenology of annual and deciduous plants, shrubland VI time series have sharper seasonal variations than forest VI time series, as well as a sharper and more rapid response to climatic conditions (Clark et al. 2010, Arambarri et al. 2011). These kinds of variations in VI time series might generate $\mathrm{QVI}_{\mathrm{TS}_{\mathrm{b}} / \mathrm{TS}_{\mathrm{ub}}}$ time series with high noise levels and abrupt variations. The presence of high noise levels in time series can reduce the probability to detect significant results in traditional tests, such as the Spearman test used to detect trends (Yue et al. 2002). Therefore, the method might be affected by the inter- and intra-annual differences in behavior of forest and shrubland covers.

The proposed method is only based on functional similarity; however, structural similarity should be taken into account if we want to obtain unburned control sites highly similar to burned sites. Therefore, the availability of vegetation maps with good accuracy and few misclassified pixels is a key issue in implementing the proposed method successfully. Nevertheless, it is necessary to distinguish the effect of omission and commission errors. Omission errors have no effect on the results obtained by the tests used in the proposed 
method since they are pixels of a given vegetation cover, but were classified as a different vegetation cover (Lillesand et al. 2008). In other words, if the method looks for forest data, pixels of this vegetation cover incorrectly labeled will be ignored. Nevertheless, the presence of omission errors in the vegetation map reduces the number of potential candidate sites to be tested, and this could be a problem if the vegetation cover under study is scarce. The presence of commission errors in the vegetation map could generate problems in the results obtained by the tests used in the proposed method. The commission errors are pixels that were mistakenly classified as the determined vegetation cover (Lillesand et al. 2008).

This situation represents a problem only if the $\mathrm{QVI}_{\mathrm{TS}_{\mathrm{b}} / \mathrm{TS}_{\mathrm{ub}}}$ series calculated from VI series obtained from different vegetation covers successfully meets the three proposed criteria. Nevertheless, since the dominant vegetation covers of our system have very different structural (Atala et al. 2008, Arambarri et al. 2011) and functional (Clark et al. 2010) characteristics, we expect that only a small quantity of $\mathrm{QVI}_{\mathrm{TSb} / \mathrm{TSub}}$, constructed with VI time series of different vegetation covers, meet the three proposed criteria. However, this could generate problems in systems in which the different vegetation covers have similar structural and functional characteristics. Therefore, we recommend checking the results with free, very high spatial resolution images, like GeoEye or QuickBird (Google Earth, https://www.google. com/earth//).

The mode of implementing the proposed statistical tests may have some drawbacks. The Friedman test was implemented using 12 averaged data points (four seasons and three years) to reduce autocorrelation problems (Morettin and Castro Toloi 1985, Sutradhar et al. 1995). However, this procedure implies losing some of the information contained in the time series. The limitations mentioned would generate problems in the method implementation since Friedman test often fails to detect statistically significant differences in data sets with high variance (Yue et al. 2002), as is expected for shrubland QVI time series. Thus, the method would select unburned sites with VI time series that did not meet the proposed biological criteria and with extreme differences from the VI time series of the burned site. To avoid selecting unburned sites with VI time series showing extreme differences from the VI time series of the burned site, Lhermitte et al. (2010) proposed to remove these kinds of time series using Limit Values obtained through MSE (i.e., an empirical threshold estimated from the distribution of the data pool, which is used as a rule of thumb to accept or reject time series). Better results may be obtained by calculating the Limit Value using the WCI data, since this measure presents a proportional reduction smaller than MPD and MSE differences (Figures 6 and 7). We propose to use the median of the WCI data as Limit Value (between 0.05 and 0.08 for this work), which ensures the selection of the best quality data and the rejection of only half of the possible unburned control sites. However, we emphasize that the need to use arbitrary Limit Values to obtain satisfactory results implies that some of the biological information still has not been correctly modeled. As a consequence, some $\mathrm{QVI}_{\mathrm{TS}_{\mathrm{b}} / \mathrm{TS} \text { ub }}$ time series that meet the three proposed criteria were not pure random noise $a_{\mathrm{QVI}}$, as we expected for time series that lack seasonality and trend components (Morettin and Castro Toloi 1987, Brockwell and Davis 2002). Further research will be needed to determine if this is due to the need for additional biological criteria or the need for improvements in the statistical tests.

\section{CONCLUSIONS}

This method represents an advance from the conceptual and methodological standpoints; it can be used to select control sites for the study of fires as well as other disturbances such as floods, insect infestation, and droughts 
in different ecosystems. In addition, the proposed criteria can also be used to determine when the sites will recover after the fire. The biological criteria proposed in this study can provide a complete analysis since they allow us to test the mean value of $\mathrm{QVI}_{\mathrm{TS}_{\mathrm{b}} / \mathrm{TS}_{\mathrm{ub}}}$, its slope, and seasonal behavior separately, providing detailed information about the recovery process. However, the statistical slope test still needs to be adapted to detect when the slope of the $\mathrm{QVI}_{\mathrm{TS}_{\mathrm{b}} / \mathrm{TS}_{\mathrm{ub}}}$ curve becomes null.

\section{ACKNOWLEDGEMENTS}

The authors thank Dr. O. Bustos from FAMAF (Facultad de Matemática Astronomía y Física, Universidad Nacional de Córdoba) for his helpful advice to improve this research. This study was funded by grants to L.M. Bellis from SECyT-Universidad Nacional de Córdoba, FONCYT (PICT $2012 \mathrm{~N}^{\mathrm{o}}$ 1147) and CONICET (PIP N ${ }^{\circ}$ 11220090100263). M. Landi and J. Argañaraz have a fellowship from CONICET. L. Bellis and C. Di Bella are researchers at CONICET. We acknowledge the US Geological Survey for the use of Landsat images. We acknowledge Oak Ridge National Laboratory for the use of MODIS images. We acknowledge NASA FIRMS for the use of MCD14L product. We acknowledge the European Commission Joint Research Centre for the use of Globcover 2000.

\section{LITERATURE CITED}

Arambarri, M.A., M.C. Novoa, N.D. Bayón., M.P. Hernandez, M. Colares, and C. Monti. 2011. Ecoanatomia foliar de árboles y arbustos de los distritos chaqueños occidental y serrano (Argentina). Boletín de la Sociedad Argentina de Botánica 46: 251-270. [In Spanish.]

Atala, D., C. Schneider, and S. Ruffini. 2008. Mapa de cobertura forestal nativa de la provincia de Córdoba 2008. Secretaría de Ambiente de la provincial de Córdoba, Argentina. [In Spanish.]

Ayanz, S.M.J., J.D. Carlson, M. Alexander, K. Tolhurst, G. Morgan, and R. Sneeuwjagt. 2003. Current methods to assess fire danger potential. Pages 21-61 in: E. Chuvieco, editor. Wildland fire danger estimation and mapping. World Scientific Publishing, Singapore. doi: 10.1142/9789812791177_0002

Baret, F., G. Guyot, and D.J. Major. 1989. Crop biomass evaluation using radiometric measurements. Photogrammetria 43: 241-256. doi: 10.1016/0031-8663(89)90001-X

Baret, F., and G. Guyot. 1991. Potentials and limits of vegetation LAI and APAR assessment. Remote Sensing of Environment 35: 161-173. doi: 10.1016/0034-4257(91)90009-U

Bond, W.J., and J.E. Keeley. 2005. Fire as a global 'herbivore': the ecology and evolution of flammable ecosystems. Trends in Ecology and Evolution 20: 387-394. doi: 10.1016/j. tree.2005.04.025

Bravo, S., C. Kunst, M. Leiva, and R. Ledesma. 2014. Response of hardwood tree regeneration to surface fires, western Chaco region, Argentina. Forest Ecology and Management 326: 3645. doi: 10.1016/j.foreco.2014.04.009

Brockwell, P.J., and R.A. Davis. 2002. Introduction to time series and forecasting. Springer-Verlag, New York, New York, USA. doi: 10.1007/b97391

Cabello, J., N. Fernández, D. Alcaraz-Segura, C. Oyonarte, G. Piñeiro, A. Altesor, M. Delibes, and J.M. Paruelo. 2012. The ecosystem functioning dimension in conservation insights from remote sensing. Biodiversity and Conservation 21: 3287-3305. doi: 10.1007/ s10531-012-0370-7 
Casady G.M., W.J.D. Van Leeuwen, and S.E. Marsh. 2010. Evaluating post-wildfire vegetation regeneration as a response to multiple environmental determinants. Environmental Modeling and Assessment 15: 295-307. doi: 10.1007/s10666-009-9210-X

Clark, M.L., T.M. Aide, H.R. Grau, and G. Riner. 2010. A scalable approach to mapping annual land cover at $250 \mathrm{~m}$ using MODIS time series data: a case study in the Dry Chaco ecoregion of South America. Remote Sensing of Environment 114: 2816-2832. doi: 10.1016/j. rse.2010.07.001

Cuadras, C.M. 1989. Distancias estadísticas. Estadística Española 119: 295-378. [In Spanish.]

Di Bella, C.M., M.A. Fischer, and E.G. Jobbágy. 2011. Fire patterns in north-eastern Argentina: influences of climate and land use/cover. International Journal of Remote Sensing 32: 49614971. doi: 10.1080/01431161.2010.494167

Di Mauro, B., F. Fava, L. Busetto, G.F. Crosta, and R. Colombo. 2014. Post-fire resilience in the alpine region estimated from MODIS satellite multispectral data. International Journal of Applied Earth Observation and Geoinformation 32: 163-172. doi: 10.1016/j.jag.2014.04.010

Díaz-Delgado, R., F. Lloret, X. Pons, and J. Terradas. 2002. Satellite evidence of decreasing resilience in Mediterranean plant communities after recurrent wildfires. Ecology 83: 22932303. doi: 10.1890/0012-9658(2002)083[2293:SEODRI]2.0.CO;2

Diaz-Delgado, R., and X. Pons. 1997. Seguimiento de la regeneración vegetal post incendio mediante el uso de NDVI. Revista de Teledetección 12: 1-4. [In Spanish.]

Efron, B. 1979. Bootstrap methods: another look at the jackknife. The Annals of Statistics 7: 1-26. doi: 10.1214/aos/1176344552

Efron, B., and R. Tibshirani. 1986. Bootstrap methods for standard errors, confidence intervals, and other measures of statistical accuracy. Statistical Science 1: 54-75.

Eva, H.D., E.E. de Miranda, C.M. Di Bella, V. Gond, O. Huber, M. Sgrenzaroli, S. Jones, A. Coutinho, A. Dorado, M. Guimarães, C. Elvidge, F. Achard, A.S. Belward, E. Bartholomé, A. Baraldi, G. De Grandi, P. Vogt, S. Fritz, and A. Hartley. 2002. A vegetation map of South America. European Commission Joint Research Centre, Office for Official Publications of the European Communities, Luxembourg.

Flannigan, M., S.A. Cantin, W.J. de Groot, M. Wotton, A. Newbery, and L.M. Gowman. 2013. Global wildland fire season severity in the 21 st century. Forest Ecology and Management 294: 54-61. doi: 10.1016/j.foreco.2012.10.022

Franzini, L., and A.C. Harvey. 1983. Testing for deterministic trend and seasonal components in time series models. Biometrika 70: 673-682. doi: 10.1093/biomet/70.3.673

Gao, X., R.A. Huete, W. Ni, and T. Miura. 2000. Optical-biophysical relationships of vegetation spectra without background contamination. Remote Sensing of Environment 74: 609-620. doi: 10.1016/S0034-4257(00)00150-4

Gasparri, N.I., G.M. Parmuchi, J. Bono, H. Karszenbaum, and C.L. Montenegro. 2010. Assessing multitemporal Landsat 7 ETM+ images for estimating above-ground biomass in subtropical dry forest of Argentina. Journal of Arid Environments 74: 1262-1270. doi: 10.1016/j. jaridenv.2010.04.007

Giglio, L. 2010. MODIS collection 5 active fire product user's guide version 2.4. University of Maryland, College Park, USA.

Gitas, I., I. Mitri, S. Veraverbeke, and A. Polychronaki. 2012. Advances in remote sensing of post-fire vegetation recovery monitoring - a review. Pages 143-176 in: L. Fatoyinbo, editor. Remote sensing of biomass - principles and applications. InTech Open, Shangai, China. doi: $10.5772 / 20571$ 
Goetz, S.J., G.J. Fiske, and A.G. Bunn. 2006. Using satellite time-series data sets to analyze fire disturbance and forest recovery across Canada. Remote Sensing of Environment 101: 352365. doi: 10.1016/j.rse.2006.01.011

Hicke, J.A., G.P. Asner, E.S. Kasischke, N.H.F. French, J.T. Randerson, G.J. Collatz, B.J. Stocks, C.J. Tucker, S.O. Los, and C.B. Field. 2003. Postfire response of North American boreal forest net primary productivity analyzed with satellite observations. Global Change Biology 9: 1145-1157. doi: 10.1046/j.1365-2486.2003.00658.x

Huete, A., K. Didam, T. Miura, E.P. Rodriguez, X. Gao, and L.G. Ferreira. 2002. Overview of the radiometric and biophysical performance of the MODIS vegetation indices. Remote Sensing of Environment 83: 195-213. doi: 10.1016/S0034-4257(02)00096-2

ITT Visual Information Solutions. 2009. IDL version 71. ITT Visual Information Solutions, Boulder, Colorado, USA.

Joint Research Centre. 2000. Global land cover 2000. < <http://forobs.jrc.ec.europa.eu/products/ glc2000/products.php>. Accessed 7 September 2016.

Key, C.H., and N.C. Benson. 1999. The Normalized Burn Ratio (NBR): a Landsat TM radiometric measure of burn severity. US Department of the Interior, Northern Rocky Mountain Science Center, Bozeman, Montana, USA.

Kovalskyy, V., D.P. Roy, X.Y. Zhang, and J. Ju. 2012. The suitability of multi-temporal web-enabled Landsat data NDVI for phenological monitoring - a comparison with flux tower and MODIS NDVI. Remote Sensing Letters 3(4) 325-334.

Kunst, C., S. Bravo, and J.L. Panigatti. 2003. Fuego en los ecosistemas Argentinos. Ediciones INTA, Santiago del Estero, Argentina. [In Spanish.]

Lhermitte, S., J. Verbesselt, W.W. Verstraeten, and P. Coppin. 2010. A pixel based regeneration index using time series similarity and spatial context. Photogrammetric Engineering \& Remote Sensing 76: 673-682. doi: 10.14358/PERS.76.6.673

Lhermitte, S., J. Verbesselt, W.W. Verstraeten, and P. Coppin. 2011. A comparison of time series similarity measures for classification and change detection of ecosystem dynamics. Remote Sensing of Environment 115: 3129-3152. doi: 10.1016/j.rse.2011.06.020

Lillesand, T.M., R.W. Kiefer, and J.W. Chipman. 2008. Remote sensing and image interpretation. John Willey \& Sons, Hoboken, New Jersey, USA.

McKenzie, D., C. Miller, and D.A. Falk., editors. 2011. The landscape ecology of fire. Springer, New York, New York, USA.

McLeod, A.I., K.W. Hipel, and B.A. Bodo. 1991. Trend analysis methodology for water quality time series. Environmetrics 2: 169-200. doi: 10.1002/env.3770020205

Morettin, P.A., and C. Toloi. 1987. Previsao de séries temporais. Editorial Atual, São Paulo, Brazil. [In Portuguese.]

Paruelo, J.M. 2008. La caracterización funcional de ecosistemas mediante sensores remotos. Ecosistemas 17: 4-22. [In Spanish.]

Paruelo, J.M., and W.K. Lauenroth. 1998. Interannual variability of NDVI and its relationship to climate for North American shrublands and grasslands. Journal of Biogeography 25: 721733. doi: 10.1046/j.1365-2699.1998.2540721.x

Paruelo, J.M., E.G. Jobbágy, and O.E. Sala. 2001. Current distribution of ecosystem functional types in temperate South America. Ecosystems 4: 683-698. doi: 10.1007/s10021-001-0037-9

Paruelo, J., C.M. Di Bella, and M. Milkovic. 2014. Percepción remota y sistemas de información geográfica. Editorial Hemisferio Sur, Ciudad Autónoma de Buenos Aires, Buenos Aires, Argentina. [In Spanish.] 
Perez-Cabello, F., M.T. Echeverría, P. Ibarra, and J. Riva. 2009. Effects of fire on vegetation, soil and hydrogeomorphological behavior in Mediterranean ecosystems. Pages 111-128 in: E. Chuvieco, editor. Earth observation of wildland fires in Mediterranean ecosystems. Springer, New York, New York, USA. doi: 10.1007/978-3-642-01754-4_9

Riaño, D., E. Chuvieco, S. Ustin, R. Zomer, P. Dennison, D. Roberts, and J. Salas. 2002. Assessment of vegetation regeneration after fire through multitemporal analysis of AVIRIS images in the Santa Monica Mountains. Remote Sensing of Environment 79: 60-71. doi: 10.1016/ S0034-4257(01)00239-5

Rosenqvist, A. 1996. The global rain forest mapping project by JERS-1 SAR. International Archives of Photogrammetry and Remote Sensing 31(Part B7): 594-598.

Saint, G. 1994. "VEGETATION" onboard SPOT-4 mission specifications, version 3. European Commission Joint Research Centre, Ispra, Varese, Italy.

Sheskin, D.J. 2004. The Kruskal-Wallis one-way analysis of variance by ranks. Pages 757-794 in: D.J. Sheskin, editor. Handbook of parametric and nonparametric statistical procedures. Chapman \& Hall, New York, New York, USA.

Sutradhar, B.C., I.B. MacNeil, and E.B. Dagum. 1995. A simple test for stable seasonality. Journal of Statistical Planning and Inference 43: 157-167. doi: 10.1016/0378-3758(94)00016-O

USGS [US Geological Survey]. 2005. GTOPO30 documentation. <https://webgis.wr.usgs.gov/ globalgis/gtopo30/>. Accessed 1 March 2017.

Van Leeuwen, W.J.D. 2008. Monitoring the effects of forest restoration treatments on post-fire vegetation recovery with MODIS multitemporal data. Sensors 8: 2017-2042. doi: 10.3390/ s8032017

Van Leeuwen, W.J.D., G.M. Casady, D.G. Neary, S. Bautista, J.A. Alloza, Y. Carmel, L. Wittenberg, D. Malkinson, and B.J. Orr. 2010. Monitoring post-wildfire vegetation response with remotely sensed time-series data in Spain, USA and Israel. International Journal of Wildland Fire 19: 75-93. doi: 10.1071/WF08078

Veraverbeke, S., I. Gitas, T. Katagis, A. Polychronaki, A. Somers, and R. Goossens. 2012. Assessing post-fire vegetation recovery using red-near infrared vegetation indices: accounting for background and vegetation variability. ISPRS Journal of Photogrammetry and Remote Sensing 68: 28-39. doi: 10.1016/j.isprsjprs.2011.12.007

Wittenberg, L., D. Malkinson, O. Beeri, A. Halutzy, and N. Tesler. 2007. Spatial and temporal patterns of vegetation recovery following sequences of forest fires in a Mediterranean landscape, Mt. Carmel Israel. CATENA 71: 76-83. doi: 10.1016/j.catena.2006.10.007

Yue, S., P. Pilon, and G. Cavadias. 2002. Power of the Mann-Kendall and the Spearman's rho test for detecting monotonic trends in hydrological series. Journal of Hydrology 259: 254271. doi: 10.1016/S0022-1694(01)00594-7

ZáVody, A.M., M.R. Gorman, D.J. Lee, D. Eccles, C.T. Mutlow, and D.T. Llewellyn-Jonesh. 1994. The ATSR data processing scheme developed for the EODC. International Journal of Remote Sensing 15: 827-843. doi: 10.1080/01431169408954119

Zuloaga, F.O. and O. Morrone. 1999. Catálogo de plantas vasculares de la Republica Argentina II. Acanthaceae-Zygophyllaceae. Missouri Botanical Garden Press, St. Louis, Missouri, USA. [In Spanish.] 